\title{
Chinese Perspectives
}

on $\mathrm{Al}$ and Future

Military Capabilities

CSET Policy Brief

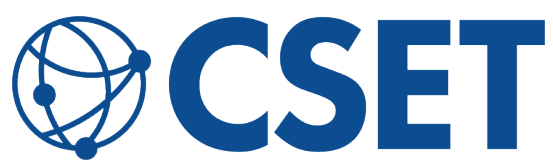

\section{AUTHOR}

Ryan Fedasiuk 


\section{Executive Summary}

For all the attention given to how the U.S. military should plan for great power competition with China-and the role of artificial intelligence in that competition-U.S. observers have spent far less time discussing Chinese perspectives of the same. English-language studies that do focus on the role of $\mathrm{Al}$ in China's military outlook have rightly focused on the corpus of highranking military leaders' statements and official PLA planning and policy documents. But high-level strategic plans are poor indicators of $\mathrm{Al}$ development in practice, and risk criticism that public statements from Beijing should be dismissed as "cheap talk." ${ }^{1}$

A supplementary approach to understand the Chinese military's thinking on Al is to read what People's Liberation Army (PLA) officers, defense industry engineers, and academics involved in the day-to-day development and deployment of Al are writing about the technology.

This study constructs a framework for systematically assessing arguments about $\mathrm{Al}^{\prime}$ 's effect on military capabilities and strategic stability. It applies the framework to 58 journal articles written from 2016-2020 by PLA officers, defense industry engineers, and academics at leading Chinese universities (hereafter "experts") about artificial intelligence and future weapons systems.

Key findings include the following:

\section{Chinese experts forecast that $A$ / will improve detection, targeting, and} strikes against military targets. They are optimistic about the advantages of machine learning to track or strike at forces and lower the costs of signaling or deploying force-primarily through intelligent munitions, unmanned aerial vehicles, and intelligence, surveillance, and reconnaissance (ISR) software. At the same time, Chinese experts were concerned that a reliance on $\mathrm{Al}$ would leave systems vulnerable to adversarial examples, and that cyber vulnerabilities could threaten command and control systems.

\section{Chinese experts believe advances in A/ will undermine strategic stability,} both in general and in terms of China's deterrence relationship with the United States. They most often argued that Al could increase the risk of miscalculation or escalation in conflicts and reduce the ability to retaliate. Chinese experts are particularly concerned that American advances in $\mathrm{Al}$ could overwhelm Chinese air defenses, increase the vulnerability of Chinese command and control systems, or reduce China's time to respond to an 
imminent attack-mainly as a result of the Al-enabled AGM-158C Long Range Anti-Ship Missile, automated vulnerability detection and exploitation in cyberspace, or decision support and training software.

\section{Chinese experts tend to overestimate U.S. military A/ capabilities, relative} to open-source reporting. Chinese discussions of U.S. Al projects resemble Cold War concerns over a "missile gap" between the United States and the Soviet Union. Chinese experts overestimated U.S. capabilities, at times citing outdated or inaccurate projections of U.S. investments and force postures that make use of "intelligentized" weapons (智能化武器).

\section{Chinese machine learning engineers face significant hurdles in developing} and deploying Al applications, including constraints on the technical literacy of service members and the availability of data and computing power. At the same time, they worry that Chinese advancements in Al could proliferate outside the country, and have taken steps to secure information and prevent technology transfer to the United States.

\section{Policy Recommendations}

American readers might find comfort in the fact that Chinese experts think U.S. Al capabilities exceed their own. However, many Chinese experts remain concerned that $\mathrm{Al}$ developments in either country could undermine strategic stability or risk unintended escalation. An effective U.S. strategy to contain Chinese military Al development should preserve America's apparent advantages in $\mathrm{Al}$ while minimizing the impulse to race toward unpredictable, unproven weapons systems. At the same time, the United States can take steps to mitigate concerns about escalation risks.

1. Maintain the U.S. Al advantage by constraining the PLA's access to data, personnel, and critical advanced semiconductors. This report challenges the notion that the U.S. military lags behind the PLA in a race to adopt AI. Rather, Chinese journal articles in this study indicate that the PLA faces three major obstacles in adopting Al: limited access to data, insufficient security clearances and technical literacy among personnel, and a dearth of high-end microprocessors required to develop and run advanced neural networks. U.S. policymakers would be remiss to ignore the PLA's struggles. The U.S. government has several tools at its disposal to improve U.S. advantages in data, personnel, and hardware, while restricting the Chinese military's access to the same. 
2. Avoid arms racing. Rather than immediately pursue the most promising Al capabilities, U.S. military leaders should carefully consider the costs and benefits of developing certain Al systems-for example, an ISR system designed to autonomously track Chinese road-mobile transporter-erectorlaunchers. ${ }^{2}$ It is unclear whether or to what extent China may hold back Al development in response to U.S. restraint. However, Chinese experts frequently point to their capability gap with the United States as justification for accelerating research and investment in Al and intelligent weaponry.

3. Mitigate escalation risk. To reduce the risk of miscalculation or inadvertent escalation, the United States must actively coordinate with rival powers. ${ }^{3}$ Maintaining a stable nuclear future will demand that the United States undertake both confidence-building measures and assertive negotiations with Chinese counterparts. U.S. negotiations with China to proscribe certain autonomous weapons or $\mathrm{Al}$ capabilities should remain separate from broader efforts to constrain China's nuclear arsenal. 
Table of Contents

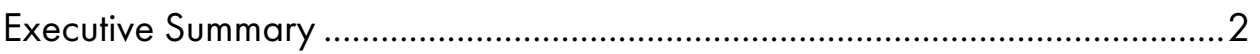

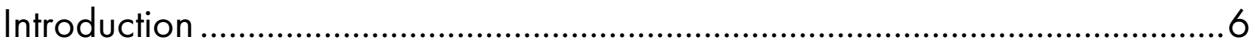

Chinese and American Conceptions of Artificial Intelligence .........................6

Chinese and American Conceptions of Strategic Stability ............................... 8

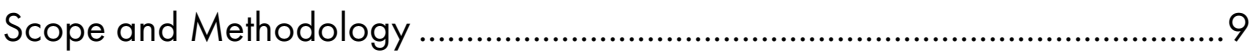

A Framework for Understanding Arguments About Al .............................. 10

Extracting Causal Arguments About Al and Warfighting......................... 11

How Chinese Experts Expect Al Will Affect Future Warfare .......................... 14

Largest Perceived Threats to China's Military from U.S. Al ....................... 16

Implications for Strategic Stability ............................................................... 17

Chinese Perspectives on U.S. Al Projects......................................................... 18

Barriers to Al Development in the People's Liberation Army ......................... 19

Data Collection and Processing..................................................................... 19

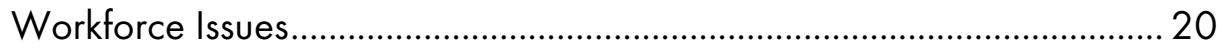

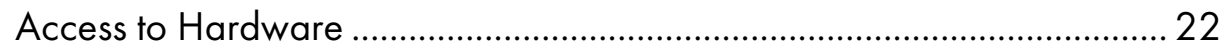

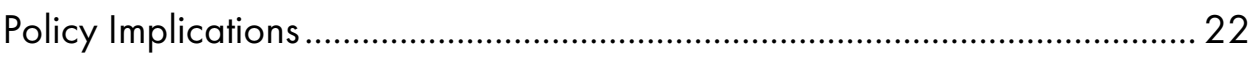

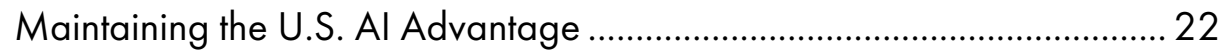

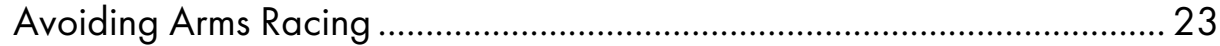

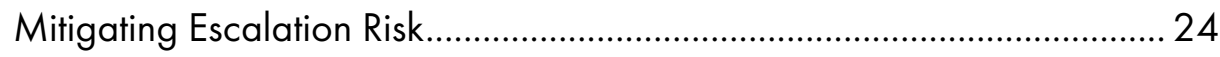

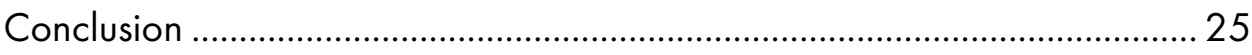

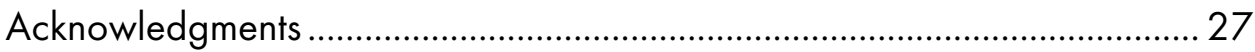

Appendix: Selecting a Universe of Papers ..................................................... 28

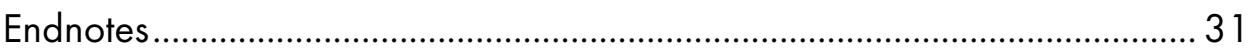




\section{Introduction}

In the last minutes of Stanley Kubrick's Dr. Strangelove, when pressed as to why his country had developed such an outrageous, automated "doomsday machine," Russian ambassador Alexei de Sadeski replies that it had "cost us just a small fraction of what we'd been spending on defense in a single year. But the deciding factor was when we learned that your country was working along similar lines, and we were afraid of a doomsday gap." Kubrick's film is celebrated for its gallows humor and incisive critique of deterrence theory. But 56 years later, the central plot device-" an automated and irrevocable decision making process which rules out human meddling" - is being discussed to varying degrees by militaries worldwide. ${ }^{4}$

As research and investment in artificial intelligence has climbed, military analysts and academics have questioned how $\mathrm{Al}$ could affect the future of warfare. ${ }^{5}$ But U.S. defense planners have paid far less attention to Chinese experts' attitudes toward $\mathrm{Al}$-in part because accessible, English-language analyses of Chinese thinking are limited. ${ }^{6}$

This study is a structured meta-analysis of Chinese scholarship. It constructs a framework for systematically assessing Chinese arguments about artificial intelligence and strategic stability, and applies that framework to 58 papers published between 2016 and 2020 by Chinese military officers, defense industry engineers, and scholars at leading civilian universities. Chinese experts vary in which features of Al technology they assume to be the most important, the effects they expect Al to have on military operations, and the strategic effects of improved or reduced warfighting capabilities.

The study first summarizes Chinese and American conceptions of Al and strategic stability, then details the methodology for extracting arguments from Chinese literature. The bulk of the paper quantifies and analyzes how Chinese experts expect Al will affect future warfare. It concludes by highlighting three major obstacles the PLA faces in developing and deploying $\mathrm{Al}$ and intelligent weapons: limitations in data collection and processing, workforce issues, and access to microprocessors.

\section{Chinese and American Conceptions of Artificial Intelligence}

Notwithstanding the Chinese government's narrow definition of lethal autonomous weapon systems, Chinese and American experts generally agree on descriptions of how automation and autonomy function in 
weapons. ${ }^{7}$ Like their American counterparts, Chinese scientists and academics envision applying artificial intelligence to "weaponized platforms and auxiliary operating systems, including intelligent command and control systems, drones, unmanned vehicles, ground robots, unmanned surface boats, unmanned submersibles, " among other platforms. ${ }^{8}$ Collectively, the Chinese journal articles in this study refer to at least 12 discrete applications of artificial intelligence, comprising both "intelligentized" weapon platforms and software. These include autonomous or unmanned aerial, surface, undersea, or ground vehicles; intelligent munitions; intelligent satellites; intelligence, surveillance, and reconnaissance (ISR) software; automated cybersecurity software; automated cyberattack software; decision support software; automated missile launch software; and software used in cognitive electronic warfare.

"Artificial intelligence" itself is famously difficult to define. There are real differences between $\mathrm{Al}$, machine learning, automation, and autonomy, but it is beyond the scope of this paper to disambiguate them at the technical level. ${ }^{9}$ The Chinese papers included in this study refer broadly to artificial intelligence (人工智能) and machine learning (机器学习), which can encompass autonomy (自主) and automation (自动化) to varying degrees. Chinese journal articles in this study tended to describe Al as a technology that uses machine-based algorithms in conjunction with large datasets to produce improved, iterated learning. They refer to $\mathrm{Al}$ in weapons systems as including autonomy or automation related to decision-making.

However, in predicting the effect of artificial intelligence on future warfare, both Chinese and American scholars often conflate the benefits of autonomy and remote control. Myriad articles predict that autonomous weapons will lower the economic and political costs of signaling or deploying military force, yet these are not unique features of artificial intelligence or autonomy: humans are already absent from remotely piloted UAVs. ${ }^{10}$ Writing for Military Digest(军事文摘), Ding Ning and Zhang Bing clarify succinctly: "Unmanned weapons are not equivalent to intelligentized weapons. Only when weapons and equipment have changed qualitatively from 'automation' to 'autonomy, with the characteristics of 'autonomy' and 'intelligence,' can they be called 'intelligentized' weapons and equipment." "' Within this study, however, the author does not discriminate between Chinese experts' arguments about artificial intelligence and those seemingly predicated on the unmanned nature of certain weapons platforms. 


\section{Chinese and American Conceptions of Strategic Stability}

The notion of "strategic stability" is ambiguous among American nuclear scholars. Writing for the Army War College, Elbridge Colby and Michael Gerson refer to at least three types of stability: first-strike stability, whereby all parties understand that "massively launching first-whether to avoid being neutered or to try to disarm one's opponent-would be either unnecessary or foolish"; crisis stability, in which leaders do not feel "pressures, including psychological ones, that would push a crisis towards spinning out of control"; and arms race stability, a situation where adversaries pursue changes in force structure "manifestly designed to conform to the enduring reality of mutual vulnerability rather than as plausible attempts to gain strategic superiority." 12

Chinese military experts do not depart wildly from American academics in their descriptions of strategic stability (战略稳定). Several papers in this study discuss the concepts of first-strike stability, crisis stability, and arms race stability, or taxonomize the concepts identically to Colby and Gerson. ${ }^{13}$ However, Chinese experts depart from Americans in which capabilities they consider to be destabilizing, according to their different security environments, military capabilities, and world outlooks. ${ }^{14}$

Chinese defense planners are more optimistic about their ability to control escalation in crises than their American counterparts, which has led some American analysts to argue against pursuing a damage-limitation or counterforce nuclear strategy. ${ }^{15}$ But differing perspectives on the "clandestine counterforce hedge" - the idea that capabilities that make winning a war more likely can make deterrence more likely to fail, because they undermine the precarious balance of terror that underpins stability-have been a sticking point in American interpretations of Chinese nuclear policy. ${ }^{16}$ While some U.S. scholars have pointed to the counterforce hedge as a reason to doubt China's "No First Use" nuclear policy or more seriously consider the possibility Beijing will pursue greater automation, others have interpreted Chinese confidence in escalation control as a reason to trust the credibility of its NFU commitment. ${ }^{17}$

Among the papers in this study, Chinese experts often pointed to the counterforce hedge to criticize the development of U.S. military capabilities, but not their own. According to Jiang Jingchun, a PLA Army Captain at China's National University of Defense Technology, there are two goals in accelerating the development of military intelligence and situational awareness: to "modernize China's national defense and build a world-class 
military," 18 and to "enhance our ability to control crises and contain wars, thereby maintaining regional and world peace. ${ }^{\prime 19}$

What the warfighting effects of Al will be, which capabilities should be considered stabilizing, and under what conditions, are the central axes around which Chinese and American defense scholars differ in their beliefs about $\mathrm{Al}$ and strategic stability. ${ }^{20}$ But despite Chinese military planners' optimistic view of escalation control, Chinese journal articles in this study concluded overwhelmingly that artificial intelligence will be strategically destabilizing.

\section{Scope and Methodology}

Several conditions limit the findings of this study. First, artificial intelligence is a burgeoning area of scholarship; this paper narrowly describes how Chinese experts think Al will or is likely to be applied in future warfighting and deterrence scenarios. Second, some translation errors may have occurred. Fluent Chinese speakers at CSET translated many of the documents and checked the quotations, but machine translation largely informed the analysis. Third, this study measures how frequently Chinese experts made certain arguments about $\mathrm{Al}$ and warfighting; the upper echelons of Chinese military leadership may not buy into the ideas being presented in academic journals. Additionally, these findings rely on published, scholarly literature in China. While comprehensive, the database used-the China National Knowledge Infrastructure-may inadequately capture the most influential Chinese thought on these issues or overlook emerging ideas in technical fields. Finally, the paper categorizes constituent parts of larger Chinese arguments about warfighting and deterrence; the author could have misunderstood or mislabeled some of the papers in the dataset.

Of the 58 papers included in this study, 18 were by authors directly affiliated with the People's Liberation Army or its military academies; 26 were by researchers or engineers employed in China's defense industry; 10 were by professors working at civilian universities; two were published by the Chinese government (by the Ministry of Foreign Affairs and the China Patriotic Engineering Federation); and two lacked authors or otherwise did not list an affiliation. 


\section{A Framework for Understanding Arguments About Al}

This study categorizes Chinese experts' arguments according to two independent variables (features of $\mathrm{Al}$ and the types of systems in which $\mathrm{Al}$ is situated) and three dependent variables (warfighting capability, strategic effect, and net effect on strategic stability). This framework also records some context for Chinese authors' arguments, including which country they argue might use Al or experience its effects. The overall framework is summarized in this table:

Table 1. A Framework for Deconstructing Arguments About Al.

\begin{tabular}{|c|c|c|c|}
\hline$A$ feature of $A$ l & in a type of system & $\begin{array}{l}\text { operated by a } \\
\text { country }\end{array}$ & can alter \\
\hline $\begin{array}{c}\text { Improved Efficiency } \\
\text { of Operations } \\
\text { Removal of Human } \\
\text { Judgment } \\
\text { Novelty or } \\
\text { Uncertainty About } \\
\text { Weapon } \\
\text { Functionality } \\
\text { The Networked and } \\
\text { Blended Nature of } \\
\text { Information Relays } \\
\text { Susceptibility to } \\
\text { Adversarial } \\
\text { Examples }\end{array}$ & $\begin{array}{c}\text { UAV } \\
\text { USV } \\
\text { UUV } \\
\text { UGV } \\
\text { Intelligent Munition } \\
\text { Intelligent Satellite } \\
\text { ISR Software } \\
\text { Automated Cyber } \\
\text { Defense } \\
\text { Automated Cyberattack } \\
\text { Decision Support } \\
\text { Automated Missile } \\
\text { Launch } \\
\text { Cognitive Electronic } \\
\text { Warfare }\end{array}$ & $\begin{array}{l}\text { A Country } \\
\text { OR } \\
\text { Its Adversary }\end{array}$ & $\begin{array}{c}\text { Increase } \\
\text { OR } \\
\text { Reduce }\end{array}$ \\
\hline $\begin{array}{l}\text { a warfighting } \\
\text { capability }\end{array}$ & for a country's military, & thereby producing & a strategic effect. \\
\hline $\begin{array}{c}\text { Attack Response } \\
\text { Time } \\
\text { Probability of } \\
\text { Technical Failure } \\
\text { Cost of Signaling or } \\
\text { Expending Force }\end{array}$ & $\begin{array}{l}\text { A Country } \\
\text { OR } \\
\text { Its Adversary }\end{array}$ & $\begin{array}{c}\text { Increase } \\
\text { OR } \\
\text { Reduce }\end{array}$ & $\begin{array}{c}\text { Risk of } \\
\text { Miscalculation or } \\
\text { Unintended/Inadver } \\
\text { tent Escalation } \\
\text { Favorability of } \\
\text { Preemptive Strike }\end{array}$ \\
\hline
\end{tabular}

\footnotetext{
*Adversarial examples are "inputs to machine learning models that an attacker has intentionally designed to cause the model to make a mistake; they're like optical illusions for machines." See "Attacking Machine Learning with Adversarial Examples," OpenAl, February 24, 2017, https://openai.com/blog/adversarial-example-research/.
} 


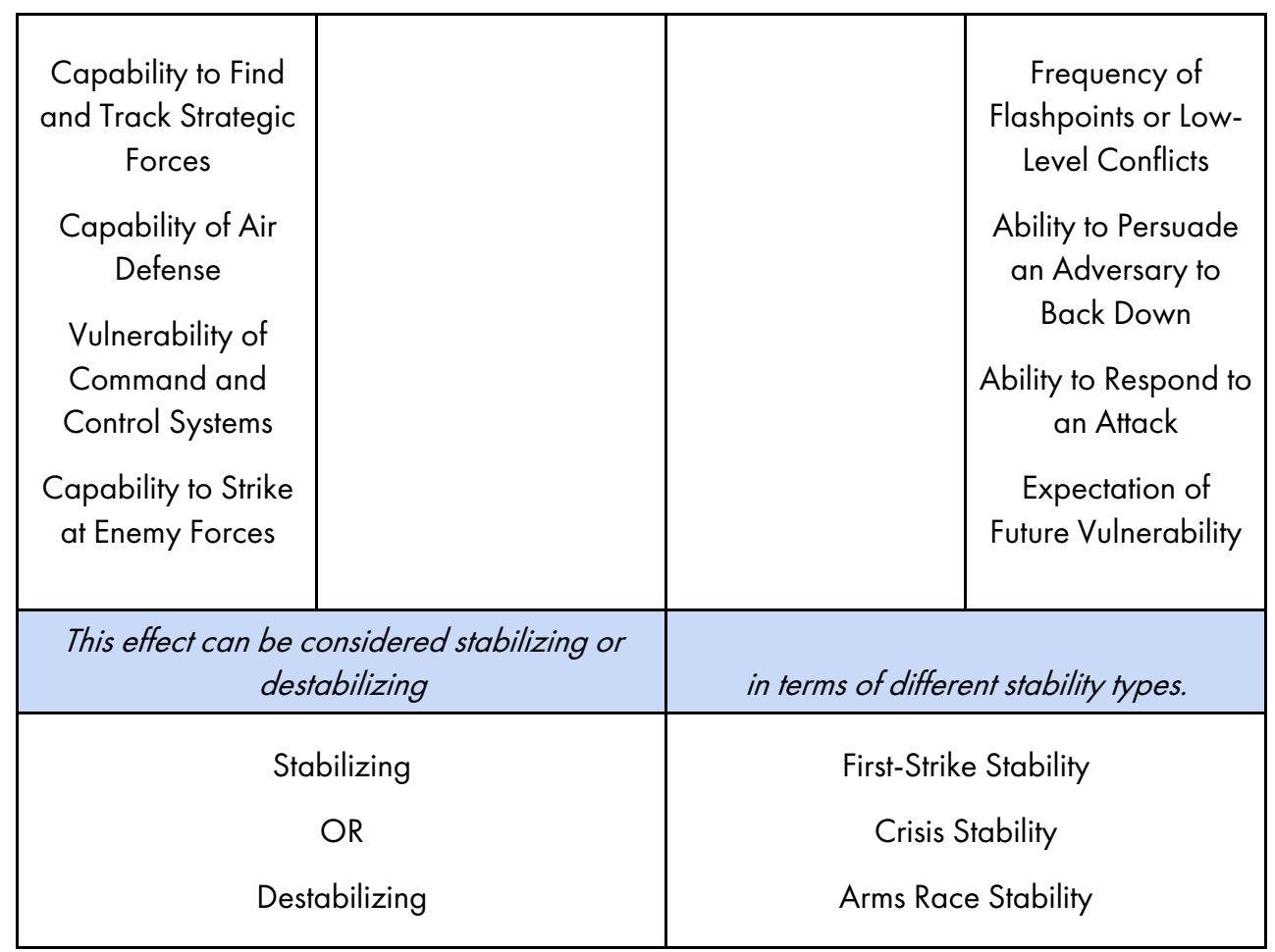

\section{Extracting Causal Arguments About Al and Warfighting}

The author read 123 papers hosted in China National Knowledge Infrastructure (CNKI) and deconstructed the assumptions of each argument that related Al to warfighting according to the framework presented above. A full breakdown of Chinese papers used in this study can be found in the Appendix. Each paper made several arguments about a wide variety of issues, but only 58 papers directly and specifically related artificial intelligence to future warfighting capabilities.

Reading and interpreting written arguments is necessarily subjective. This study adopted an inductive and iterative coding process based on three variables: all arguments in the paper identified a unique feature of artificial intelligence (IV-1) which, when situated in a type of weapon system (IV-2), would produce some kind of operational effect (DV-1). ${ }^{\dagger}$ For example:

\footnotetext{
${ }^{\dagger}$ The number of possible arguments $(10,080)$ is constrained by the literature selected. When encountering a new argument that did not fit the existing model, the author added additional categories as appropriate. For example, the author did not expect Chinese experts to discuss "generic" Al, nor intelligent satellites, and added those options ad hoc. Other Chinese papers could have made arguments not rationalizable according to the model above.
} 
The [absence of human operators] in [unmanned aerial vehicles] operated by [the United States] can [reduce] the [cost of signaling or expending force] for [the United States].

The [susceptibility to adversarial examples] in [ISR software] operated by [China] can [increase] the [probability of technical failure] for [China].

The [improved efficiency of operations] in [automated cyberattack software] operated by [the United States] can [increase] the [vulnerability of C2 systems] for [China].

Chinese experts tended to discuss each variable in the following ways:

Features of Al: When discussing why Al would produce an operational effect, Chinese experts referred to at least one of five features of the technology: (1) its ability to improve efficiency and scalability, mainly by reducing the size, weight, power, or cost of operations; (2) the removal of humans from decision-making or combat; (3) novelty or uncertainty about weapon functionality; (4) the networked and blended nature of information relays in distributed networks; or (5) the susceptibility of machine learning systems to adversarial examples. ${ }^{21}$

Types of Systems: In making arguments, Chinese experts frequently discussed how Al could be applied in discrete military applications. This study identified 12 categories of military applications of Al: UAVs, USVs, UUVs, UGVs, intelligent munitions, intelligent satellites, ISR software, automated cyber defense software, automated cyberattack software, decision support software, automated missile launch software, and cognitive electronic warfare software. ${ }^{22}$ The dataset also identifies whether the argument was specifically about the effect of a swarm of vehicles, as opposed to an individual platform. In some cases, Chinese experts did not specify an application; these cases are labeled "generic Al."

Actors: Chinese experts often discussed how Al could affect military operations in the abstract, and only sometimes specified whether they were referring to military applications belonging to the United States or China. Several other articles specifically reviewed the advantages of Russian, Japanese, or Israeli Al capabilities. Data coding distinguishes between when Chinese experts discussed reducing some adversary's capability, as opposed to improving one's own. 
Effects on Military Operations: The dependent variable-the warfighting capability Al could improve or impair-was the most difficult to code. Chinese experts generally concluded that Al would increase or reduce one of seven features of wartime operations: (1) attack response time; (2) the cost of signaling or expending force; $(3)$ the capability to find and track strategic forces; (4) the capability of air defense systems; (5) the vulnerability of command and control systems; (6) the capability to strike at enemy forces; or (7) the probability of technical failure. ${ }^{23}$

In turn, many scholars went on to extrapolate their arguments, predicting that operational effects of Al would produce a secondary dependent variable, strategic effect (DV-2) of consequence to national security. For example:

By [reducing] the [capability of air defense] for [China], Al would [increase] the [probability of a preemptive strike].

By [reducing] the [attack response time] for [the United States], Al would [increase] the [risk of miscalculation or escalation].

By [increasing] the [ambiguity between conventional and nuclear forces] for [China], Al would [increase] the [ability to persuade adversaries to back down in a crisis].

Effects on Strategic Planning: The predicted strategic effect of Al varied according to the changes in military capabilities Chinese experts expected $\mathrm{Al}$ would bring about. They generally concluded that Al would increase or reduce one of six features related to deterrence: (1) the risk of miscalculation or escalation; (2) the favorability of a preemptive strike; (3) the frequency of flashpoints or low-level conflicts; (4) the ability to persuade adversaries to back down in a conflict; (5) the ability to respond to an attack, or (6) the expectation of future force vulnerability.

Effects on Strategic Stability: Finally, some scholars even went so far as to predict a net effect on strategic stability (DV-3), in general or specifically in terms of China's relationship with the United States. For example:

By [increasing] the [favorability of a preemptive strike], Al would be [destabilizing] in the context of [first-strike stability].

By [increasing] the [probability of miscalculation or escalation], Al would be [destabilizing] in the context of [crisis stability].

By [decreasing] the [expectation of future vulnerability], Al would be [stabilizing] in the context of [arms race stability]. 


\section{How Chinese Experts Expect AI Will Affect Future Warfare}

This study identified 122 arguments that related Al to warfighting capabilities, presented across 58 of the original 123 papers in the dataset. ${ }^{\ddagger}$ These are Chinese experts' eight most common arguments about how $\mathrm{Al}$ could affect military operations, and the number of times they were presented across the articles in this study:

\section{Table 2. Chinese Experts Predict Al Will Make Military Forces More} Vulnerable.

\begin{tabular}{|l|r|}
\hline Predicted Effect of Al on Military Operations & Count \\
\hline $\begin{array}{l}\text { The improved efficiency of operations in intelligent munitions operated } \\
\text { by a country can increase the capability to strike at enemy forces for } \\
\text { that country. }\end{array}$ & 11 \\
\hline $\begin{array}{l}\text { The improved efficiency of operations in ISR software operated by a } \\
\text { country can increase the capability to find and track strategic forces for } \\
\text { that country. }\end{array}$ & 10 \\
\hline $\begin{array}{l}\text { The improved efficiency of operations in UUVs operated by a country } \\
\text { can increase the capability to find and track strategic forces for that } \\
\text { country. }\end{array}$ & 6 \\
\hline $\begin{array}{l}\text { The absence of humans in UAVs operated by a country can reduce the } \\
\text { cost of signaling or expending force for that country. }\end{array}$ & 6 \\
\hline $\begin{array}{l}\text { The improved efficiency of operations in automated cyberattack } \\
\text { software operated by a country can increase the vulnerability of C2 } \\
\text { systems for its adversary. }\end{array}$ & 5 \\
\hline $\begin{array}{l}\text { The improved efficiency operations in automated cyber defense } \\
\text { software operated by a country can reduce the vulnerability of C2 } \\
\text { systems for that country. }\end{array}$ & 5 \\
\hline $\begin{array}{l}\text { The improved efficiency of operations in UAVs operated by a country } \\
\text { can increase the capability to find and track strategic forces for that } \\
\text { country. }\end{array}$ & 5 \\
\hline $\begin{array}{l}\text { The networked and blended nature of information relays in UAVs } \\
\text { operated by a country can increase the capability to strike at enemy } \\
\text { forces for that country. }\end{array}$ & 5 \\
\hline Other arguments made fewer than five times each, across the literature. & \\
\hline
\end{tabular}

‡ Sixty-five papers did not expressly make an argument about how Al would affect warfighting capabilities. Of the 58 papers that did, scholars frequently repeated similar arguments. 
Chinese experts were most optimistic that "intelligentized" weaponry, unmanned aerial vehicles, and ISR software would improve warfighting capabilities for both themselves and their adversaries. They most commonly believed Al would improve the ability to track and strike at enemy forces, while reducing the cost of signaling or expending force.

Figure 1. Counts of Expected Improvements in Warfighting Capabilities, by Application of Al.

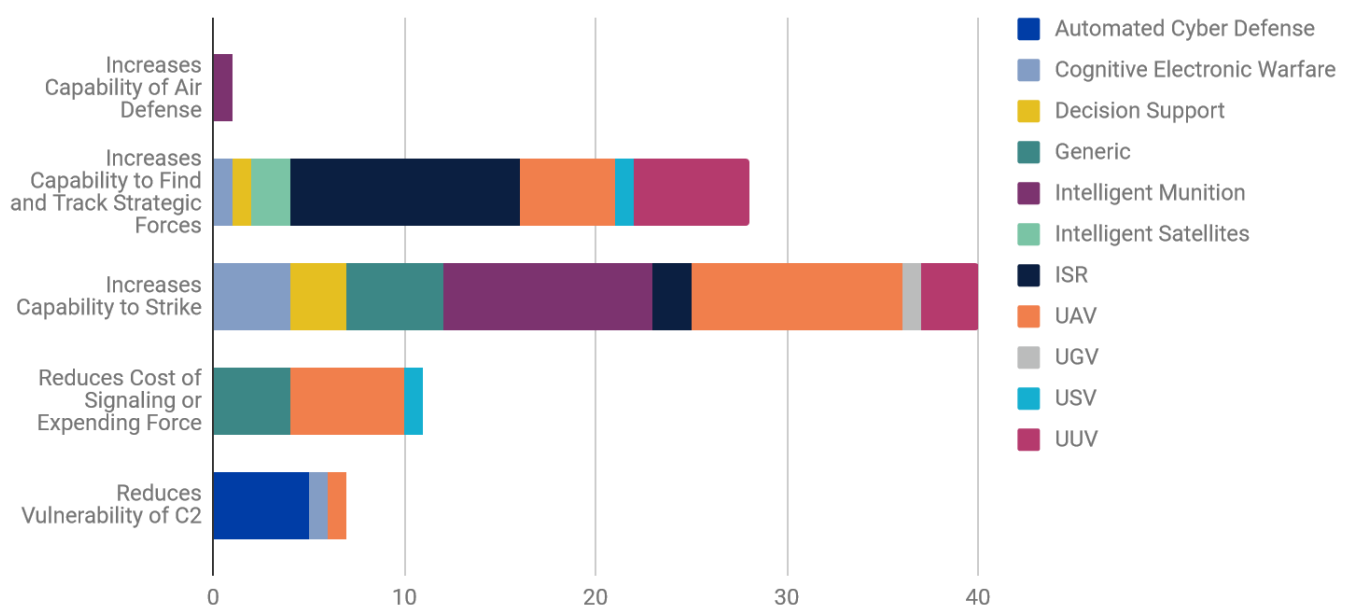

However, scholars also forecasted that Al writ large, in particular decision support and automated cyberattack software, would increase the vulnerability of command and control systems and the probability of technical failure in military systems, while reducing the capability of air defenses.

Figure 2. Counts of Expected Reductions in Warfighting Capabilities, by Application of $A /$.

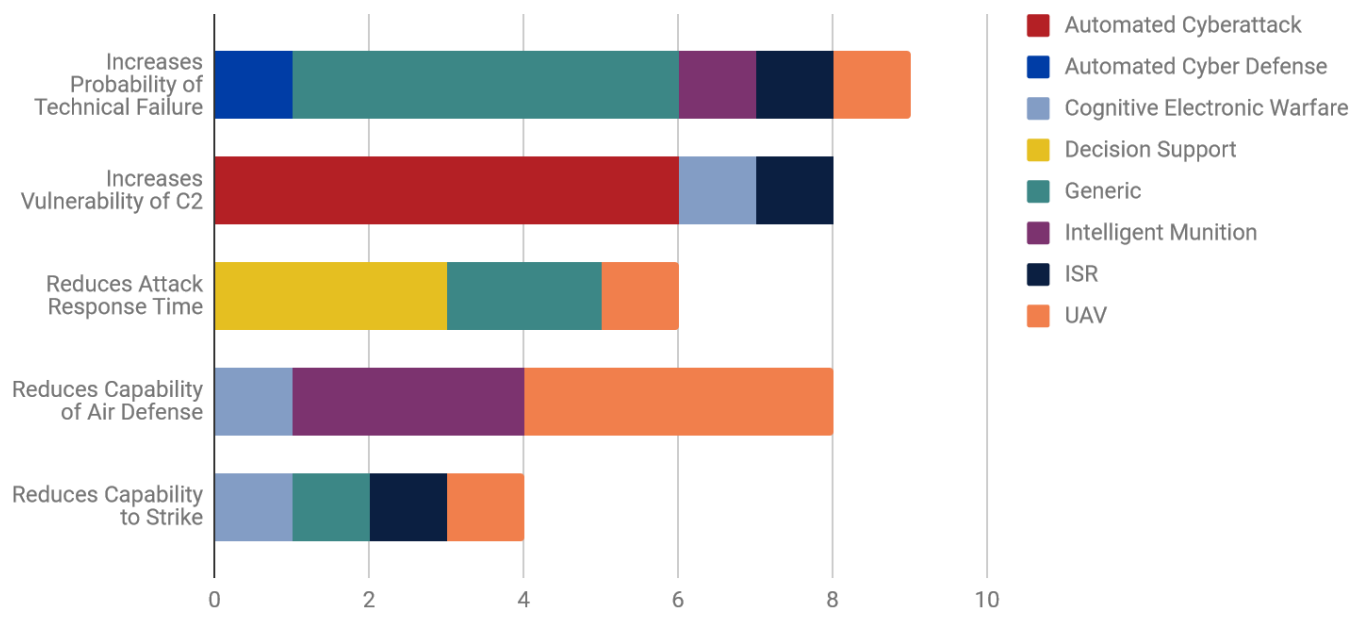


In 12 cases, Chinese experts argued that a specific U.S. application of AI would threaten China by reducing the capability of Chinese air defenses, increasing the vulnerability of Chinese command and control systems, or reducing the PLA's time to respond to an attack.

Table 3. Chinese Experts Worry U.S. Military Al Developments Will Threaten China

\begin{tabular}{|l|r|}
\hline Predicted Effect of U.S. Al Application & Count \\
\hline Reduces the capability of Chinese air defenses & 6 \\
\hline Increases the vulnerability of Chinese C2 systems & 4 \\
\hline \\
Reduces PLA's time to respond to an attack & 2 \\
\hline
\end{tabular}

Chinese experts most frequently voiced concerns about:

- $\quad$ The Al-enabled AGM-158C Long Range Anti-Ship Missile (LRASM). ${ }^{24}$ Developed by Lockheed Martin, the LRASM can autonomously detect a preprogrammed target, descend toward it, verify the target, and detonate. ${ }^{25}$ It is designed for use against "highpriority enemy targets like aircraft carriers, troop transport ships, and guided-missile cruisers." 26

- Soffware designed for automated computer vulnerability exploitation. ${ }^{27} \mathrm{Xu}$ Guibao, Senior Project Director at the China Academy of Information and Communication Technology (中国信息 通信研究院) and principal author of China's "Three-Year Action Plan for Promoting Development of a New Generation Al Industry," estimated that the U.S. National Security Agency could "remotely attack about 70 percent of Windows machines worldwide," posing serious risks to Chinese consumers and industries that use the operating system. ${ }^{28}$

- The "ALPHA" air combat simulation software developed at the University of Cincinnati. ${ }^{29}$ ALPHA is a training simulation tool for unmanned combat air vehicles that aims to "increase autonomous capabilities to allow mixed combat teams of manned and unmanned air fighters to operate in highly contested environments." ${ }^{30}$ 
Fewer Chinese experts argued artificial intelligence would change war at a more fundamental, strategic level. Of the 122 arguments that discussed how Al would affect military operations, Chinese experts predicted a broader effect on strategic planning in only 32 cases (26 percent). Chinese experts were most concerned that $\mathrm{Al}$ would increase the risk of miscalculation or escalation in a crisis, and that $\mathrm{Al}$ systems would reduce the ability to respond to attacks.

Table 4. Chinese Experts Worry Al Will Increase Escalation Risks.

\begin{tabular}{|l|r|}
\hline Predicted Effect of Al on Strategic Planning & Count \\
\hline Al will increase the risk of miscalculation or escalation. & 8 \\
\hline Al will reduce the ability to respond to attacks. & 8 \\
\hline $\begin{array}{l}\text { Al will increase the ability to persuade adversaries to back down } \\
\text { in a crisis. }\end{array}$ & 3 \\
\hline Al will increase the expectation of future vulnerability. & 3 \\
\hline Al will increase the favorability of preemptive strike. & 7 \\
\hline Other unique arguments. & 3 \\
\hline
\end{tabular}

Although some effects on strategic planning seem destabilizing-for example, increasing conditions favorable to a preemptive strike-Chinese experts only sometimes extrapolated to such conclusions. In only 15 of the 122 arguments (12 percent) coded in this study, they explicitly predicted a net effect on "strategic stability" (战略稳定). However, the arguments that were about strategic stability reached an overwhelming consensus. In 12 of 15 cases (80 percent), scholars predicted that artificial intelligence would be destabilizing.

\section{Table 5. Chinese Experts Worry Al Will Undermine Strategic Stability.}

\begin{tabular}{|l|r|r|}
\hline Stability Type & Stabilizing & Destabilizing \\
\hline Arms Race Stability & 1 & 4 \\
\hline Crisis Stability & 0 & 5 \\
\hline & & \\
\hline First-Strike Stability & 2 & 3 \\
\hline
\end{tabular}


Generic or unspecified Al systems were the most common sources of Chinese concerns over strategic instability, followed by UAVs and decision support software. In just three cases, scholars hypothesized Al could be used to reinforce strategic stability:

- If automated cybersecurity software is used to defend nuclear command and control systems;

- If Chinese defense planners use Al to track the nuclear forces of other countries, "thereby enhancing national strategic nuclear deterrence confidence"; or

- If Al enables weaker states with limited resources to mitigate key gaps in their capabilities. ${ }^{31}$

\section{Chinese Perspectives on U.S. AI Projects}

Chinese experts look to the United States as a model for military Al development. Multiple papers cited U.S. officials in offices throughout the Department of Defense to highlight the scale of U.S. Al developments and investments, including Michael Griffin's 2018 congressional testimony that $592 \mathrm{Al}$ projects were underway across the U.S. defense enterprise. ${ }^{32}$ Scholars routinely presented some U.S. programs in particular as feats to be emulated or feared, including DARPA's Deep Green decision support algorithm (now canceled), the MQ-25 Stingray Carrier-Based Aerial Refueling System UAV, the AGM-158C intelligent missile, and the Algorithmic Warfare Cross-Functional Team (Project Maven). ${ }^{33}$ When discussing how Al might alter adversaries' future warfighting capabilities, 18 percent of Chinese experts' arguments identified in this study referred to specific U.S. Al systems creating vulnerabilities for China.

Chinese experts tended to overestimate the Al capabilities of the U.S. military, relative to publicly available information in English. Officers in the PLA's Strategic Support Force project that soon, "the U.S. military ... will be able to automatically exchange technical standards [required for] data exchange," which "will enable unified management of 1,000 intelligent weapons and equipment. ${ }^{134}$ Another paper claims the United States has already achieved "unified management of 'smart' weapons and equipment," and calls for PLA leaders to "determine metadata control policies, set up a global information grid metadata working group, and develop a set of core metadata and extensions standards," to capitalize on the benefits of network-centric warfare. ${ }^{35}$ In total, 36 percent of Chinese experts' arguments were about how U.S. Al systems would likely improve U.S. warfighting capabilities. 
Altogether, Chinese experts project a significant gulf between the PRC's own Al capabilities and those of the United States, overestimating U.S. progress as well as the capacity for Al to change military operations. Several journal articles presented facts with no basis in reality. More than one Chinese paper referred to, but did not cite, a 2002 projection from two Canadian authors that "by 2025, 90 percent of the U.S. military's fighter aircraft will be drones, and 10 percent will be manned aircraft." ${ }^{36}$ Another article posited that "by 2020, the U.S. Navy is expected to have 2000 to 4000 sets of unmanned submersibles" - the U.S. Navy today operates 35. ${ }^{37}$ Three other papers erroneously reported that the United States spent "between $\$ 12$ and 15 billion USD (152亿美元) in the research and development of artificial intelligence and automatic weapons" in 2017.38 Total DOD funding for AI and autonomy that year actually totaled $\$ 1.3$ billion. ${ }^{39}$ These five articles were published within the past four years; none cited their estimates, nor did they specify how they arrived at such conclusions.

Despite some exaggerations in the literature, Chinese experts are generally right that they may lag behind the United States in developing military applications of Al. However, some invented or exaggerated expectations of future vulnerability-fear of a "doomsday gap" - likely amplify Chinese concerns that $\mathrm{Al}$ will be strategically destabilizing.

\section{Barriers to Al Development in the People's Liberation Army}

Some American observers have claimed that China's military leads the United States in $\mathrm{Al}$ development and that its strategy of military-civil fusion has provided China's state-owned enterprises and national laboratories unbridled access to militarily-relevant data, equipment, and personnel. ${ }^{40}$ The findings of this report challenge that proposition. Chinese military officers, defense industry engineers, and academics at leading universities frequently complain about three major obstacles to Al development in China: data collection and processing, workforce issues, and access to hardware.

\section{Data Collection and Processing}

Chinese experts lament that a key challenge to developing autonomous weapons lies in collecting raw data. Researchers at the Shanghai Institute of Mechanical and Electrical Engineering (上海机电工程研究所) and Northern

Institute of Automatic Control Technology (北方自动控制技术研究所) point out that, "Many successful algorithms ... require a large amount of data to be 
trained. For example, AlexNet uses a deep convolutional neural network to classify 1.2 million high-resolution images into 1,000 different classes. In the context of military applications, such huge data sets are rarely available." ${ }^{41}$ Intelligent munitions are an insightful case study in Chinese data limitations: one paper by senior researchers at China Ordnance Industry Group (中国兵 器工业集团; or Norinco) references DARPA's publicly-available Moving and Stationary Target Acquisition and Recognition data set, "the only publicly available radar image data set" for militarily-relevant targets. ${ }^{42}$ Although it would be better if the PLA could directly collect high-resolution data from missile seekers, the authors write, "it is impossible to simply fire tens or hundreds of thousands of missiles and record the target data from the seekers." 43 Multiple scholars cite the lack of high-fidelity data as a barrier to China's development of intelligent munitions: "Only after obtaining a large number of training samples of the target of interest, can we extract the effective features of the target based on the data, design advanced artificial intelligence algorithms, and finally achieve high-precision intelligent selection and recognition of the target of interest." ${ }^{44}$ As a result of data limitations, "the actual [target] recognition result ... is far from meeting the expected requirements, the robustness is poor, the detection probability in low-clutter environments does not exceed 70 percent, and the false alarm rate is high." 45

Another problem lies in data storage, cleaning, and integration. Chinese experts observe that "intelligentized" munitions "require relatively high data and computer performance. The extremely limited data resources and technical power of the military sector simply cannot meet the requirements of developing intelligent weapons." 46 Although China has made progress in military-civil fusion in recent years, "our military still faces inconsistent technical standards and incompatible experimental platforms in deepening cooperation with local research institutions." 47 As a third paper concludes, "Without a prompt digital transformation, the military will not be able to effectively meet the objective needs of intelligentized warfare in the future." 48

\section{Workforce Issues}

On the question of talent, the benefits of China's military-civil fusion remain unclear. While China has accelerated its development of military-industrial enterprises, writes Liu Yao, a senior engineer at China Electronics Technology Group Corporation (中国电子科技集团; or CETC), "the high threshold for security clearances is a natural barrier for private enterprises. "49 He estimates only 10 percent of employees at private military-industrial enterprises possess required security credentials. ${ }^{50}$ Overclassification, which has famously 
blighted research in the U.S. defense industry, may also exclude some of China's top in-house talent from working on Al applications for the PLA. ${ }^{51}$ Technical literacy is also an issue. One Chinese scholar cites statistics from the Ministry of Education, writing that although 71 Chinese colleges and universities have set up artificial intelligence-related disciplines, "Al courses are still not widely offered in military academies, and there is still a major lack of technical personnel who can perform Al research in the military. ${ }^{152}$ Another study corroborates this claim: despite high pass rates, professors in the computer science department of China's National University of Defense Technology (国防科技大学) estimate that " 60 percent of the students in the university produce fewer than 1,000 lines of code in four years, and have almost no software development experience. ${ }^{153}$ Students who pass introductory machine learning courses still struggle to code in Python. ${ }^{54}$

The transfer of sensitive technical information and foreign talent to China has been a contentious issue in the United States since the mid-2010s. Yet surprisingly, Chinese researchers and military members share many of the same concerns about technology transfer-only, in the opposite direction. One engineer complains, "with the widespread application of new technologies such as Beidou satellite navigation, big data, and artificial intelligence, the stealing, penetration, and countermeasure activities of foreign hostile forces and intelligence agencies have become more frequent and diverse." ${ }^{155} \mathrm{He}$ recommends cracking down on "the security and control of confidential information, to prevent leaks"; only under "high-pressure situations" will personnel be prevented (阻止) from giving up state secrets. ${ }^{56}$ In the same vein, another engineer at China Aerospace Science and Industry Corporation posits that the Central Intelligence Agency is preying on Chinese engineers. He notes that Silicon Valley tech companies cooperate with the agency on 137 artificial intelligence processing projects and speculates that Chinese developers "seemingly sent accidental friend circle messages may have been targeted by 'artificial intelligence spies. ${ }^{\prime \prime 57}$ To "prevent the leakage of related technologies to other countries," another paper prescribes, "we must strengthen the supervision of mobile storage devices, implement access control systems for worksites, strictly prevent spies from illegally entering scientific research sites, and cut off the outflow channels of relevant technology. ${ }^{158}$ However, the same security measures are inhibiting China's military-civil fusion efforts. In part because of "the confidentiality of the tasks, and the closed-off environment, our military still faces significant problems that need to be urgently solved as they deepen cooperation with local research institutions. ${ }^{\prime 59}$ 
It is no secret that Chinese companies cannot produce the high-end, leadingedge semiconductor devices capable of running the complex neural networks required for military-grade systems. ${ }^{60}$ One paper by researchers at the Ministry of Industry and Information Technology's Chip Card Interface Device Research Institute (工信部赛迪研究院) estimates that "more than 90\% of China's high-end chips rely on imports; $100 \%$ of DRAM memory, $99 \%$ of CPU, and $93 \%$ of MEMS sensors all rely on imports from countries such as the United States, Japan and South Korea." ${ }^{61}$ Recognizing their disadvantage, Chinese experts also discussed potential remedies to China's inadequate chip production capacity. The same paper recommends exploiting China's position in the global semiconductor market to "mobilize ARM and Intel, Qualcomm and Samsung to compete with each other, and at the same time cultivate Godson, China Electronics, Hisilicon, Spreadtrum, and SMIC." 62 They also recommend accelerating China's push for foreign technical information and talent: "Chip innovation can be achieved through acquisitions, mergers and acquisitions, capital cooperation, technical cooperation, and talent recruitment," especially from neighboring Taiwan. ${ }^{63}$

\section{Policy Implications}

The findings of this report paint a bittersweet picture: Chinese military officers, engineers, and scholars worry that U.S. military Al capabilities exceed their own and complain that they lag behind in Al development. At the same time, many of them fear Al will undermine strategic stability with the United States, and could prompt unintended escalation. An effective U.S. strategy to contain Chinese military Al development would preserve America's apparent advantages in $\mathrm{Al}$ while minimizing the impulse to race toward unpredictable, unproven weapons systems.

\section{Maintaining the U.S. Al Advantage}

This report's findings challenge the notion that the U.S. military is behind the PLA in a race to adopt Al. Rather, Chinese journal articles indicate the PLA is struggling to adopt $\mathrm{Al}$ as a result of its limited access to the data, technical information, and microprocessors needed to develop, test, and operate highend Al systems. The U.S. government has several tools it could use to improve U.S. access to data, personnel, and hardware, while restricting Chinese military access to the same. Other CSET reports have offered myriad recommendations on this front: 
- The State and Treasury Departments, U.S. Trade Representative, and relevant intelligence agencies should coordinate with U.S. allies and partners to build an empirical knowledge base about technology transfer, supported by robust data collection and analysis. ${ }^{64}$

- The State Department and Department of Energy can partner with allies to establish "Al economic zones" modeled on the Schengen area, which would allow researchers to work in key sectors more freely, or with added immigration incentives, provided they abide by a common set of rules and standards. ${ }^{65}$

- The Bureau of Industry and Security and the State Department should continue in their efforts to persuade U.S. allies to adopt export controls on leading-edge semiconductor manufacturing equipment. ${ }^{66}$ They should also coordinate with Taiwan to stymie the outflow of semiconductor professionals working at TSMC. ${ }^{67}$

- The Committee on Foreign Investment in the United States should seek to expand its list of "excepted foreign states" under the Foreign Investment Risk Review Modernization Act by persuading U.S. allies to adopt comprehensive investment review procedures. ${ }^{68}$

- Relevant U.S. agencies should consider sharing certain types of nonsensitive data and collaborating on AI R\&D with allies and partners. ${ }^{69}$ Taken together, the United States and its allies comprise a majority of global R\&D spending, far exceeding that of Beijing. ${ }^{70}$

\section{Avoiding Arms Racing}

Arms race dynamics surrounding Al are particularly concerning because applications of the technology are so new and uncertain. Rather than immediately pursue the most promising Al capabilities, U.S. military and defense industry leaders should carefully consider the costs and benefits of developing certain capabilities. ${ }^{71}$ Research by leading American Al and military scholars indicates that states may feel compelled to automate parts of the nuclear command, control, and communications (NC3) architectures if they lack confidence in the survivability of their nuclear arsenals. ${ }^{72}$ The Chinese literature surveyed in this study overwhelmingly concluded that $\mathrm{Al}$ would be destabilizing for this very reason.

- The Joint Artificial Intelligence Center, Office of Net Assessment, and Strategic Capabilities Office should commission studies modeling Chinese responses to certain U.S. military Al developments-for example, autonomous TEL tracking, submarine detection, or UAV swarming to penetrate air defenses. 
- U.S. diplomatic and defense officials should increase the frequency and scope of official and Track 1.5 dialogues with Chinese counterparts related to conflict resolution, such as the Shangri La Dialogue. ${ }^{73}$ These exchanges should include technical personnel from China's military universities and research centers, such as state key laboratories, to provide sobering perspectives on the state of the technology.

- The State Department and U.S. defense attachés should reassure Chinese military leaders of the purposes and capabilities of certain publicly known, Al-related weapon systems being pursued by the U.S. military. Similar to how the Missile Defense Agency previously published details about its missile tests, the Strategic Capabilities Office and DARPA could consider publishing more publicly available reports about successes and failures encountered during experiments and Al-related competitions. ${ }^{74}$ Doing so could credibly convey American military power while mitigating unfounded Chinese anxiety over capability gaps. In return, U.S. diplomats could demand more transparency from PLA and Chinese defense industry Al projects.

\section{Mitigating Escalation Risk}

To reduce the risk of miscalculation or unintended escalation, the United States must actively coordinate with rival powers. ${ }^{75}$ Dialogue can be uncomfortable or misinterpreted as "weakness," but maintaining a stable nuclear future will demand that the United States undertake confidencebuilding measures as well as assertive negotiations with Chinese counterparts. Whether or how U.S. policymakers should address Chinese concerns about Al and escalation depends on whether the United States adopts a damage limitation or counterforce nuclear policy with respect to China; and to what extent that strategy may be predicated on deliberately manipulating, not mitigating, the risk of escalation in a crisis. ${ }^{76}$

- As Al projects transition to programs of record, U.S. Strategic Command and the Office of the Undersecretary of Defense for Policy may want to clarify Al's role in U.S. conventional and nuclear force postures. U.S. defense officials could clearly delineate which Albased weapon systems and ISR platforms-for example, drone swarms-are designed to support tactical or strategic operations, or both. Signaling the boundaries of Al-enabled weapons would reduce the chance that such systems may be targeted accidentally during an adversary's show of force, preventing an escalatory spiral. On the 
other hand, this study demonstrates that Chinese optimism over escalation control does not necessarily extend to Al-enabled weapons. U.S. defense planners could see this as an opportunity to automate parts of the U.S. NC3 architecture, thereby exploiting Chinese apprehension-but at enormous risk to the United States. ${ }^{77}$ Although both Beijing and Washington collocate nuclear and conventional weapons, defense planners in both countries should treat Al-based systems with extra caution, and should avoid automating parts of the detect-to-engage sequence in the hope that the other side might be more forcefully deterred. ${ }^{78}$

- If the United States does reject a counterforce nuclear strategy, then U.S. diplomats should consider pursuing a signed commitment with China to restrict integration of machine learning into any stage of nuclear command, control, and communications networks. ${ }^{79}$ Although Al holds promise for intelligence operations, uncertainty about its robustness, reliability, and safety make it inappropriate to delegate tasks or fire strategic weapons for the foreseeable future. ${ }^{80}$ Such a commitment would reassure all parties regardless of the outcome of the New START Treaty or other nuclear arms control agreements, and should remain independent of broader negotiations seeking to constrain China's nuclear weapons stockpile.

- The Joint Artificial Intelligence Center should stand up a line of effort specifically dedicated to Al safety and security. Chinese and American scholars are concerned about the potential of adversarial examples to disrupt $\mathrm{Al}$-based weapons or intelligence systems, yet $\mathrm{Al}$ safety has not been the primary focus of industry nor DOD investment, despite JAIC's pivot to warfighter support in 2020.81

\section{Conclusion}

This study analyzes Chinese experts' arguments about Al and future warfighting capabilities reflected in the China National Knowledge Infrastructure. It finds Chinese military officers, defense industry engineers, and academics are optimistic about $\mathrm{Al}^{\prime}$ 's advantage in tracking or striking at strategic forces and lowering the costs of signaling or deploying forceprimarily through the use of intelligent munitions, UAVs, and ISR software. At the same time, experts are particularly concerned that American advances in artificial intelligence could reduce the capability of Chinese air defenses, increase the vulnerability of Chinese command and control systems, or reduce China's time to respond to an imminent attack - mainly through the 
AGM-158C Long Range Anti-Ship Missile and automated cyberattack or decision support software.

On balance, Chinese experts believe advances in artificial intelligence will be destabilizing, both in general and in terms of China's deterrence relationship with the United States. Despite Chinese defense planners' general optimism in their ability to control escalation, the journal articles in this study most commonly concluded that $\mathrm{Al}$ could increase the risk of miscalculation or escalation in conflicts, at the same time reducing militaries' abilities to retaliate. This study also suggests that, for the time being, scientists in China have reached the same conclusion as Dr. Strangelove at the end of the eponymous film: automating missile launch is "not a practical deterrent for reasons which, at this moment, must be all too obvious." No papers in this study discussed the advantages of automating missile launch procedures, and few, if any, predicted artificial intelligence would be applied in this way. ${ }^{82}$

Chinese discussions of U.S. Al projects mirror Cold War concerns over a "missile gap" between the United States and the Soviet Union. ${ }^{83}$ Chinese experts frequently overestimated U.S. Al capabilities relative to public reporting, at times citing outdated or inaccurate projections of U.S. investments and force postures-and used such exaggerations to justify calls to increase Chinese research and investment in the same. Chinese scientists and engineers working on military applications of artificial intelligence believe they face significant technical hurdles, including constraints on the availability of data and computing power, and worry that Chinese advancements in $\mathrm{Al}$ could proliferate outside the country. However, both China and the United States face obstacles in developing artificial intelligence, and several applications appear well beyond the grasp of either military-at least, for now. ${ }^{84}$ 


\section{Acknowledgments}

This research was first presented at the 2020 Deterrence and Assurance Academic Alliance Conference hosted by U.S. Strategic Command and the University of lowa. Informal feedback from several conference attendees and staff aided in editing the study.

The author would like to thank Daniel Chou and Jennifer Melot for their support in wrangling CNKI papers, and without whom this study would not have been possible. He is especially grateful to Scott Harold and Caitlin Talmadge for their comprehensive reviews, and to Ben Murphy, who edited translations of several critical documents. This paper also benefited from advice in early research design from Ben Chang and Margarita Konaev; and suggestions on style and content from Tarun Chhabra, Rebecca Gelles, Andrew Imbrie, Elsa Kania, Igor Mikolic-Torreira, Alexandra Vreeman, and Lynne Weil. The author is solely responsible for any errors.

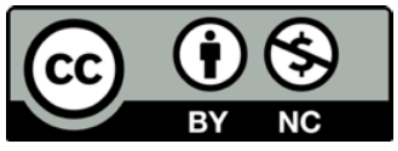

(C) 2020 by the Center for Security and Emerging Technology. This work is licensed under a Creative Commons Attribution-Non Commercial 4.0 International License.

To view a copy of this license, visit: https://creativecommons.org/licenses/by-nc/4.0/.

Document Identifier: doi: $10.51593 / 20200022$ 
This study is based on a structured meta-analysis of arguments made in papers catalogued in the China National Knowledge Infrastructure. All CNKI content was furnished as machine-readable data files for off-platform use by East View Information Services, Minneapolis, MN, USA.

CNKI is the largest database of Chinese scholarship in the world, jointly administered by Tsinghua University, the Ministry of Education, the Ministry of Science and Technology, and the Propaganda Department of the Communist Party of China. ${ }^{85}$ The database contains over 33 million articles from 7,800 academic journals published in China since $1994 .^{86}$

A CNKI snapshot was generated on February 19, 2020. The author aggregated the CNKI papers published between January 2016 and January 2020 with abstracts that contained the following combinations of keywords related to $\mathrm{Al}$, weaponry, and nuclear deterrence: ${ }^{87}$

\begin{tabular}{|l|r|l|r|}
\hline English Keywords & $\begin{array}{l}\text { No. of } \\
\text { Papers }\end{array}$ & Chinese Keywords & $\begin{array}{r}\text { No. of } \\
\text { Papers }\end{array}$ \\
\hline $\begin{array}{l}\text { deterrence + artificial } \\
\text { intelligence }\end{array}$ & 0 & 威慑 + 人工智能 & 0 \\
\hline deterrence + machine learning & 1 & 威惙 + 机器学习 & 2 \\
\hline $\begin{array}{l}\text { nuclear weapons + artificial } \\
\text { intelligence }\end{array}$ & 2 & 核武器 +人工智能 & 13 \\
\hline $\begin{array}{l}\text { nuclear weapons + machine } \\
\text { learning }\end{array}$ & 0 & 核武器 + 机器学习 & 0 \\
\hline $\begin{array}{l}\text { strategic stability + artificial } \\
\text { intelligence }\end{array}$ & 0 & $\begin{array}{l}\text { 战略稳定 + 人工智 } \\
\text { 能 }\end{array}$ & 4 \\
\hline
\end{tabular}




\begin{tabular}{|l|r|l|r|}
\hline $\begin{array}{l}\text { strategic stability + machine } \\
\text { learning }\end{array}$ & 0 & $\begin{array}{l}\text { 战略稳定 }+ \text { 机器学 } \\
\text { 习 }\end{array}$ & 0 \\
\hline weapon + artificial intelligence & 73 & 武器 + 人工智能 & 192 \\
\hline
\end{tabular}

After omitting duplicate returns, PhD dissertations, and course syllabi, 123 academic papers about $\mathrm{Al}$ and weapons systems, deterrence, or strategic stability remained in the final dataset. ${ }^{88}$ The author read each of them and, applying the framework described above, coded 122 arguments from 58 papers that explicitly discussed how Al would affect future military capabilities.

Of the 58 papers included in the study, 18 were by authors directly affiliated with the People's Liberation Army or its military academies; 26 were by researchers or engineers employed in the Chinese defense industry; 10 were by professors working at civilian universities; two were published by the Chinese government (by the Ministry of Foreign Affairs and the China Patriotic Engineering Federation); and two lacked authors or otherwise did not list an affiliation.

Most papers pertained to military science and security studies, or were technical papers that explored the application of neural networks in cognitive electronic warfare, navigation, and intelligent munitions, among other systems. More than three quarters of the papers in this study were written by authors or in publications directly affiliated with the People's Liberation Army or the Chinese defense industry.

\begin{tabular}{|l|l|l|l|}
\hline \multicolumn{2}{|l|}{ Counts of Top Author Affiliations } & \multicolumn{2}{l|}{ Counts of Top Periodicals } \\
\hline $\begin{array}{l}\text { China Aerospace Science and } \\
\text { Industry Corporation (北京市 } \\
\text { 海鹰科技情报研究所) }\end{array}$ & 9 & $\begin{array}{l}\text { Military Digest } \\
\text { (军事文摘) }\end{array}$ & 7 \\
\hline $\begin{array}{l}\text { China Electronics Technology } \\
\text { Group Corporation (中国西 } \\
\text { 南电子技术研究所) }\end{array}$ & 3 & $\begin{array}{l}\text { Aerodynamic Missile Journal } \\
\text { (飞航导弹) }\end{array}$ & 3 \\
\hline
\end{tabular}




\begin{tabular}{|l|l|l|l|}
\hline $\begin{array}{l}\text { China National Defense } \\
\text { Science and Technology } \\
\text { Information Center (中国国防 } \\
\text { 科技信息中心) }\end{array}$ & 3 & $\begin{array}{l}\text { Defense Science \& } \\
\text { Technology Industry } \\
\text { (国防科技工业) }\end{array}$ & 3 \\
\hline $\begin{array}{l}\text { Fudan University } \\
\text { (复旦大学) }\end{array}$ & 3 & $\begin{array}{l}\text { Tactical Missile Technology } \\
\text { (战术导弹技术) }\end{array}$ & 3 \\
\hline $\begin{array}{l}\text { National Defense University } \\
\text { (国防大学) }\end{array}$ & 3 & $\begin{array}{l}\text { Aero Weaponry } \\
\text { (航空兵器) }\end{array}$ & 2 \\
\hline
\end{tabular}




\section{Endnotes}

'See analysis by Joel Wuthnow, "Deciphering China's Intentions: What Can Open Sources Tell Us?," The Asan Forum, July 29, 2019, http://www.theasanforum.org/decipheringchinas-intentions-what-can-open-sources-tell-us/; and Joshua Shifrinson (@shifrinson), Twitter thread reviewing "the salience of 'cheap talk,'" Twitter, May 11, 2020, 1 1:05 a.m., https://twitter.com/shifrinson/status/1259862258030727171.

${ }^{2}$ Edward Geist and Andrew Lohn, "How Might Artificial Intelligence Affect the Risk of Nuclear War?", RAND Corporation, 2018,

https://www.rand.org/content/dam/rand/pubs/perspectives/PE200/PE296/RAND PE 296.pdf.

${ }^{3}$ Geist and Lohn, "How Might Artificial Intelligence Affect the Risk of Nuclear War?"

${ }^{4}$ Paul Scharre, "Meet the New Robot Army," Wall Street Journal, April 11, 2018, https://www.wsj.com/articles/meet-the-new-robot-army-1523455200.

${ }^{5}$ Robert Work and Eric Schmidt, "In Search of Ideas: The National Security Commission on Artificial Intelligence Wants You," War On the Rocks, July 18, 2019, https://warontherocks.com/2019/07/in-search-of-ideas-the-national-securitycommission-on-artificial-intelligence-wants-you/.

${ }^{6}$ Lora Saalman and Elsa Kania have been at the forefront of showcasing Chinese attitudes toward military applications of Al. See Saalman, "The Impact of Artificial Intelligence on Strategic Stability and Nuclear Risk, Volume II: East Asian Perspectives," Stockholm International Peace Research Institute, October 2019,

https://www.sipri.org/publications/2019/other-publications/impact-artificial-intelligencestrategic-stability-and-nuclear-risk-volume-ii; and Kania, "Chinese Military Innovation in the Al Revolution," The RUSI Journa/ 164, no. 5-6 (November 2019): 26-34, https://www.tandfonline.com/doi/abs/10.1080/03071847.2019.1693803.

${ }^{7}$ For the official Chinese government's position LAWS, see analysis by Elsa Kania, "China's Strategic Ambiguity and Shifting Approach to Lethal Autonomous Weapons Systems," Lawfare, April 17, 2018, www.lawfareblog.com/chinas-strategic-ambiguity-and-shiftingapproach-lethal-autonomous-weapons-systems. For U.S. scholars' definitions, see distinctions drawn between humans "in the loop," "on the loop," and "out of the loop" in Paul Scharre, Army of None (New York: W.W. Norton \& Company, 2018); Michael T. Klare, "Autonomous Weapons Systems and the Laws of War," Arms Control Today, March 2019, https://www.armscontrol.org/act/2019-03/features/autonomous-weaponssystems-laws-war; and Vincent Boulanin and Maaike Verbruggen, "Mapping the Development of Autonomy in Weapon Systems," Stockholm International Peace Research Institute, November 2017, https://www.sipri.org/publications/2017/otherpublications/mapping-development-autonomy-weapon-systems.

${ }^{8}$ Ding Ning and Zhang Bing, "The World's Major Military Powers Development of Intelligentized Weapons and Equipment" [世界主要军事强国的智能化武器装备发展], Military Digest, January 1, 2019, 
https://kns.cnki.net/KCMS/detail/detail.aspx?dbcode=CJFQ\&dbname=CJFDLAST2019\&f ilename $=J S W N 201901009 \& v=$ MiA1 MDFYQ1VSN3FmWU9acOZpamxXN3ZBTHo3Y1I MRzRIOWpNcm85RmJZUjhIWDFMdXhZUzdEaDFUM3FUcldNMUY=.

"See helpful explanations in "Artificial Intelligence and National Security," Congressional Research Service, November 21, 2019, https://fas.org/sgp/crs/natsec/R45178.pdf; and Andrew llachinski, "Artificial Intelligence \& Autonomy: Opportunities and Challenges," Center for Naval Analyses, October 2017, https://apps.dtic.mil/dtic/tr/fulltext/u2/1041749.pdf.

${ }^{10}$ Several scholars acknowledge that advantages come equally from "autonomous or remote controlled systems"; see Wang Xiaofeng, "The Development of Artificial Intelligence and Network Weapons" [人工智能和网络武器的发展], Information Security and Communications Privacy, March 10, 2019, https: $/ /$ kns.cnki.net $/$ KCMS $/$ detail/detail.aspx? dbcode $=$ CJFQ\&dbname $=$ CJFDLAST2019\&f ilename $=$ TXBM201903007\&v=MjYxMDU3RzRIOWpNckk5RlkOUjhIWDFMdXhZUzdEaDF UM3FUcldNMUZyQ1VSN3FmWU9ac0Zpam5WcidPTVRYSIk=. Remotely-piloted UAVs can lower the political and economic costs of conflict, as observed in John Schaus and Kaitlyn Johnson, "Unmanned Aerial Systems' Influences on Conflict Escalation Dynamics," Center for Strategic and International Studies, August 7, 2018, https://aerospace.csis.org/unmanned-aerial-systems-influences-on-conflict-escalationdynamics/.

" Ding Ning and Zhang Bing, "The World's Major Military Powers Development of Intelligentized Weapons and Equipment." Another paper puts it poetically: "The game of future wars will eventually be a game of intelligent algorithms. Unmanned platform technology is the foundation, but intelligent algorithms are the soul." See Li Fenglei, Lu Hao, Song Chuang, and Hao Mingrui, "Intelligentized Warfare and the Development of Unmanned Systems Technology" [智能化战争与无人系统技术的发展], Unmanned Systems Technology, July 15, 2018, https://kns.cnki.net/KCMS/detail/detail.aspx?dbcode=CJFQ\&dbname=CJFDLAST2018\&f ilename=UMST201802005\&v=MDkwODIxTHV4WVM3RGgxVDNxVHJXTTFGckNVUjdxZ IIPWnNGaXZoVnJyQU1DRFIlckcOSDluTXJZOUZZWVI4ZVg=.

12 Elbridge A. Colby, "Defining Strategic Stability: Reconciling Stability and Deterrence," in Strategic Stability: Contending Interpretations (Carlisle: U.S. Army War College Press, 2013) 48-59. https://publications.armywarcollege.edu/pubs/2216.pdf.

${ }^{13}$ Shi Bin, "The Basic Historical Experience of Great Powers in Building Strategically Stable Relations" [大国构建战略稳定关系的基本历史经验], China Information Security, August 15, 2019, https://kns.cnki.net/KCMS/detail/detail.aspx?dbcode=CJFQ\&dbname=CJFDLAST2019\&f ilename $=$ CINS201908016\&v=MTc1OTJwNDIFWW9SOGVYMUx leFITNORoMVQzcVRy V00xRnJDVVI3cWZZT 1 pzRml2blZMMOFKaVRGZmJHNEg5akO=.

${ }^{14}$ In "Reflections on Strategic Stability," Lu Yin argues that "the two major components of strategic stability between the United States and the Soviet Union-crisis stability and arms 
race stability - are also applicable to the United States and China today, "but function differently than they did between the United States and the Soviet Union. See Li Bin and Tong Zhao, Understanding Chinese Nuclear Thinking (Washington: Carnegie Endowment for International Peace, 2016): 129, https://carnegieendowment.org/files/ChineseNuclearThinking Final.pdf.

${ }^{15}$ See Burgess Laird, "War Control: Chinese Writings on the Control of Escalation in Crisis and Conflict," Center for a New American Security, April 2017, https://s3.amazonaws.com/files.cnas.org/documents/CNASReport-ChineseDescalationFinal.pdf? mtime =20170328141457; Fiona S. Cunningham and M. Taylor Fravel, "Dangerous Confidence? Chinese Views on Nuclear Escalation," International Security 44, no. 2 (Fall 2019): 61-109, https://www.mitpressjournals.org/doi/abs/10.1162/isec_a_00359; and Charles L. Glaser and Steve Fetter, "Should the United States Reject MAD? Damage Limitation and U.S. Nuclear Strategy Toward China," International Security 41, no. 1 (Summer 2016): 49-98, https://cpb-us-el.wpmucdn.com/blogs.gwu.edu/dist/b/1590/files/2018/08/Shouldthe-United-States-Reject-MAD-Damage-Limitation-and-U.S.-Nuclear-Strategy-towardChina-27i9iqk.pdf.

${ }^{16}$ See the "clandestine counterforce hedge" defined by Erik Gartzke and Jon Lindsay in "Thermonuclear Cyberwar," Journal of Cybersecurity 3, no. 1 (March 2017): 37-48; for the original "balance of terror," see Albert Wohlstetter, "The Delicate Balance of Terror," RAND Corporation, 1958, https://www.rand.org/pubs/papers/P1472.html.

${ }^{17}$ See Caitlin Talmadge, "Would China Go Nuclear? Assessing the Risk of Chinese Nuclear Escalation in a Conventional War with the United States," International Security 41, no. 4 (Spring 2017): 50-92, https://www.mitpressjournals.org/doi/abs/10.1162/ISEC a 00274\#.WP-7sWkrK70; and M. Taylor Fravel, "Chapter 8: China's Nuclear Strategy since 1964," in Active Defense: China's Military Strategy since 1949 (Princeton: Princeton University Press, 2019), 236269.

${ }^{18}$ Jiang Jingchun, "Some Reflections on Accelerating the Development of China's Military Intelligence" [关于加快我国军事智能化发展的粗浅思考], National Defense, December 13, 2018, DOI:10.15969/i.cnki.1 1-2770/e.2018.1 1.007. CSET translation completed by Etcetera Language Group and edited by Ben Murphy.

19 Jiang Jingchun, "Some Reflections on Accelerating the Development of China's Military Intelligence."

${ }^{20}$ For comprehensive analysis that applies the clandestine counterforce hedge to Chinese technical literature, see Lora Saalman, "Fear of False Negatives: Al and China's Nuclear Posture," Bulletin of the Atomic Scientists, April 24, 2018,

https://thebulletin.org/2018/04/fear-of-false-negatives-ai-and-chinas-nuclear-posture/.

${ }^{21}$ Chinese experts tend to discuss artificial intelligence and network-centric warfare hand in hand; many applications of $\mathrm{Al}$ depend on a distributed sensor and communication architecture. For a detailed discussion of adversarial examples in neural networks, see 
Xiaoyong Yuan, Pan He, Qile Zhu, and Xiaolin Li, "Adversarial Examples: Attacks and Defenses for Deep Learning," arXiv.1712.07107 [cs.LG], July 7, 2018, https://arxiv.org/abs/1712.07107.

${ }^{22}$ For coding purposes, adaptive interceptors for use in air or missile defense systems were classified as "intelligent munitions." "Automated missile launch software" was coded separately where arguments concerned the automatic act of launching, not improvements in projectile guidance. Finally, although software designed to exploit or defend against computer vulnerabilities is fundamentally the same in function, the author coded these applications separately to provide context for arguments.

${ }^{23}$ For clarification and examples of technical failures in autonomous systems, see Paul Scharre, "Autonomous Weapons and Operational Risk," Center for a New American Security, February 2016, https://s3.amazonaws.com/files.cnas.org/documents/CNAS Autonomous-weaponsoperational-risk.pdf.

${ }^{24}$ Zhang Yao, Wang Yonghai, Wang Jinghua, Li Manhong, Lu Ruimin, and Wang Liyan, "Performance Analysis and Research of LRASM, the Next Generation of U.S. Anti-ship Missile" [美国下一代反舰导弹LRASM性能分析与研究], Aerodynamic Missile Journal, July 15, 2018, https://kns.cnki.net/KCMS/detail/detail.aspx?dbcode=CJFQ\&dbname=CJFDLAST2018\&f ilename $=F H D D 201807006 \& v=M i l 3 N z Z y V 00 x R n J D V V I 3 c W Z Z T 1 p z R m l y b V d y N O F J e V h Q Y$ XJHNEg5bk1 $x$ STIGWW9SOGVYMUx leFITNORoMVQzcVQ=. CSET translation completed by Etcetera Language Group and edited by Ben Murphy.

${ }^{25}$ John Keller, "Air Force asks Lockheed Martin to build three more LRASM anti-ship missile systems for high-priority targets," Military \& Aerospace Electronics, December 8, 2018, https://www.militaryaerospace.com/computers/article/16726716/air-force-askslockheed-martin-to-build-three-more-Irasm-antiship-missile-systems-for-highpriority-targets.

${ }^{26}$ John Keller, "Air Force asks Lockheed Martin to build three more LRASM anti-ship missile systems for high-priority targets."

${ }^{27}$ Xu Guibao, "Implications of U.S. Intelligent Network Offensive and Defense for Our Nation's Cyber Power" [美国智能网络攻防对我国网络强国的启示], World Telecommunications, September 1, 2017, https://kns.cnki.net/KCMS/detail/detail.aspx? dbcode $=$ CJFQ\&dbname $=$ CJFDLAST2017\&f ilename=SIDX201703010\&v=Mjk3ODBIWDFMdXhZUzdEaDFUM3FUcldNMUZyQ1VSN 3FmWU9ac0Zpcm5VYnpJTmlUUGRyRzRIOWJNckk5RVpJUig=. CSET translation completed by Etcetera Language Group and edited by Ben Murphy.

${ }^{28}$ See the Three-Year Action Plan translated by Paul Triolo, Elsa Kania, and Graham Webster, "Translation: Chinese government outlines Al ambitions through 2020," New America Foundation, January 26, 2018, https://www.newamerica.org/cybersecurityinitiative/digichina/blog/translation-chinese-government-outlines-ai-ambitions-through2020/; and analysis by Xu Guibao, "Implications of U.S. Intelligent Network Offensive and Defense for Our Nation's Cyber Power." 
${ }^{29}$ Xu Pengfei, Peng Qi, Liu Jiaqi, and Chen Yuming, "Application of Foreign Artificial Intelligence Technology in the Military Domain" [国外人工智能技术在军事领域的应用], Electronic Product Reliability and Environmental Testing, September 20, 2018, https://kns.cnki.net/KCMS/detail/detail.aspx?dbcode $=$ CJFQ\&dbname $=$ CJFDLAST2018\&f ilename $=$ DZKH2018S1076\&v=MiU3MTJUM3FUcldNMUZyQ1VSN3FmWU9ac0Zpdm $1 X$ Ny9JSVRmQVpyRzRIOW12cm85Q1lvUjhIWDFMdXhZUzdEaDE=.

${ }^{30}$ Nicholas Ernest et. al," Genetic Fuzzy based Artificial Intelligence for Unmanned Combat Aerial Vehicle Control in Simulated Air Combat Missions," Journal of Defense Management 6, no. 1 (2016): 1-7, https://www.longdom.org/open-access/genetic-fuzzy-basedartificial-intelligence-for-unmanned-combat-aerialvehicle-control-in-simulated-air-combatmissions-2167-0374-1000144.pdf.

${ }^{31}$ See analysis by Luo Xi, "Artificial Intelligence Technology May Increase the Risk of Nuclear War" [人工智能技术可能加剧核战争风险]，World Affairs，August 16，2019， http://www.cnki.com.cn/Article/CJFDTotal-SJZS201916027.htm; and Xu Nengwu and Ge Hongchang, "Thoughts on Lethal Autonomous Weapon Systems and Arms Control" [致 命性自主武器系统及军控思考], Modern International Relations, July 20, 2018.

${ }^{32}$ The article by Liu Chong, Guo Xiaobing, Sun Bo, and Deng Menjia, "Analysis of the Global Strategic Arms Race Situation" [全球战略军备竞赛态势探析], International Study Reference, February 28, 2018, https: $/ /$ kns.cnki.net $/ K C M S /$ detail/detail.aspx? dbcode $=$ CJFQ\&dbname $=$ CJFDLAST20 $18 \& f$ ilename $=X D G G 201807010 \& v=M T E 3 M T B U T X F J O U V a S V I 4 Z V g x T H V 4 W V M 3 R G g x V D N x$ VHJXTTFGckNVUidxZIIPWnNGaXJuVid2TIBTbk 1hYkcOSDk=, quotes Michael Griffin, Hearing to Receive Testimony on Accelerating New Technologies to Meet Emerging Threats: Hearing before the Committee on Armed Services, Senate, 115th Cong. (2018), https://www.armed-services.senate.gov/imo/media/doc/18-40_04-18-18.pdf.

${ }^{33}$ See analysis by Zhang Bing, Dong Hongwei, and Zhang Yunchun, "Impact of Artificial Intelligence on the National Security Strategy" [人工智能对国家安全战略的影响], Communications World, February 15, 2019, https://kns.cnki.net/KCMS/detail/detail.aspx? dbcode=CJFQ\&dbname=CJFDLAST2019\&f ilename=JSTX201904018\&v=MzEwMzZiSVI4ZVgxTHV4WVM3RGgxVDNxVHJXTTFGck NVUidxZIIPWnNGaWpoVid6SUx6N2Zkckc0SDlqTXEOOUU=; as well as Xu Guibao.

${ }^{34}$ Zhang Shen, Ji Zili, and Wang Wenhua, "Overview of the Development of U.S. Military Intelligent Weapons and Equipment" [美军智能武器装备发展概况], Military Digest, September 1, 2019, https://kns.cnki.net/KCMS/detail/detail.aspx? dbcode $=$ CJFQ\&dbname $=$ CJFDLAST2019\&f ilename $=J S W N 201917015 \& v=M i Q 4 N T k 4 Z V g x T H V 4 W V M 3 R G g x V D N x V H J X T T F G c k N V$ UjidxZIIPWnNGaXJtVkwzQUx6N2NZTEcOSDlqTnFJOUVZWVI=.

${ }^{35}$ Zhang Shen, Ji Zili, and Wang Wenhua, "U.S. Military to Speed Up the Development of Smart Weapons" [美军加快发展智能武器装备], Defense Science \& Technology Industry, August 15, 2019, 
https://kns.cnki.net/KCMS/detail/detail.aspx?dbcode=CJFQ\&dbname=CJFDLAST2019\&f ilename $=Z G B G 201908016 \& v=M T g 5 O T B o M V Q z c V R y V 00 x R n J D V V I 3 c W Z Z T 1$ pzRmlybV ZydkxQeXJKYWJHNEg5ak1wNDIFWW9SOGVYMUxleFITNOQ=.

${ }^{36}$ See, for example, Wei Yuejiang and Sun Longhai, "Artificial Intelligence-Armed

'Terminator' Army" ["终结者"人工智能武装的军队], PLA Life, January 13, 2019, http://www.cnki.com.cn/Article/CJFDTotal-JFSH201901059.htm; referring to a quote in Elinor C. Sloan and Raoul-Dandurand, The Revolution in Military Affairs: Implications for Canada and NATO (Montreal: McGill Queen's Press, 2002).

${ }^{37}$ UUV estimates by Ding Ning and Zhang Bing, "Development of Intelligent Weapons and Equipment for the World's Major Military Powers"; are 10 times higher than the U.S. Navy's FY2020 budget procurement requests over the next five years. See "Navy Large Unmanned Surface and Undersea Vehicles: Background and Issues for Congress," Congressional Research Service, December 17, 2019, https://fas.org/sgp/crs/weapons/R45757.pdf.

${ }^{38}$ See investment figures presented by Li Huili, researcher at the China Academy of Aerospace Systems Science and Engineering [中国航天系统科学与工程研究院], "Research and Thinking on Strengthening Our Country's Al National Defense Applications" [加强我国人工智能国防应用的研究与思考], Civil-Military Integration on Cyberspace, February 25, 2019, https://kns.cnki.net/KCMS/detail/detail.aspx?dbcode=CJFQ\&dbname $=$ CJFDLAST2019\&f ilename $=$ WXJM201902007\&v=MTkOMzgvSO l gWEJZNOc0SDlqTXJZOUZZNFI4ZVgxTH V4WVM3RGgxVDNxVHJXTTFGckNVUidxZIIPWnNGaXZtVnl=; by Zhang Shen, Ji Zili, and Wang Wenhua; and by Xu Guibao, "The Enlightenment of U.S. Intelligent Network Attack and Defense on China's Cyber Power." They likely refer to the FYDP laid out in 2017, which allocated $\$ 18$ billion to al/technologies related to the Third Offset Strategy, over a five-year period. See Aaron Mehta, "Defense Department Budget: \$18B Over FYDP for Third Offset," Defense News, February 9, 2016, https://www.defensenews.com/2016/02/09/defense-department-budget-18b-overfydp-for-third-offset/.

39 "Defense Investment in Artificial Intelligence," GovWin, June 6, 2018, https://govwin.com/neo/marketAnalysis/view/2825? researchTypeld=1.

${ }^{40}$ For examples, see Heather Long, "In Davos, U.S. executives warn that China is winning the Al race," The Washington Post, January 23, 2019, https://www.washingtonpost.com/business/2019/01/23/davos-us-executives-warnthat-china-is-winning-ai-race/; and Greg Williams, "Why China will win the global race for complete Al dominance," Wired, April 16, 2018, https://www.wired.co.uk/article/whychina-will-win-the-global-battle-for-ai-dominance.

${ }^{41}$ Fan Jinxiang and Liu Jia, "Challenges and Thoughts on Intelligent Guidance for Automatic Target Recognition" [精确制导自动目标识别智能化的挑战与思考], Aero Weaponry， October 22, 2018, 
https://kns.cnki.net/KCMS/detail/detail.aspx?dbcode=CJFQ\&dbname $=$ CJFDLAST2019\&f ilename $=H K B Q 201901005 \& v=M T Y 3 M j N V U j d x Z \| P W n N G a X J s V z d 6 T k x T Y k p m N O c 0 S D l q$ TXJVOUZZWVI4ZVgxTHV4WVM3RGgxVDNxVHJXTTFGckM=.

${ }^{42}$ See Lu Fugang and Chen Shichao, "Demand Analysis of Intelligent Development of Helicopter Air-to-Surface Missile Precision Strike" [直升机载空地导弹精确打击智能化发 展需求分析], Aerodynamic Missile Journal, March 15, 2019, https: $/ /$ kns.cnki.net $/ K C M S /$ detail $/$ detail.aspx? dbcode $=$ CJFQ\&dbname $=$ CJFDLAST2019\&f ilename=FHDD201903010\&v=MDc2MTJGaXJsV3I3TUI5WFBhckcOSDlaTXJJOUVaSVI4Z VgxTHV4WVM3RGgxVDNxVHJXTTFGckNVUjidxZIIPWnM=; which claims, "currently, the only publicly available radar image data set is the Moving and Stationary Target Acquisition and Recognition (MSTAR) data set supported by DARPA." CSET translation completed by Etcetera Language Group and edited by Ben Murphy. For the original dataset, see "MSTAR Public Targets," U.S. Air Force Sensor Data Management System, accessed February 24, 2020, https://www.sdms.afrl.af.mil/index.php?collection=mstar\&page=targets.

${ }^{43}$ Lu Fugang and Chen Shichao, "Demand Analysis of Intelligent Development of Helicopter Air-to-Surface Missile Precision Strike."

${ }^{44}$ Lu Fugang and Chen Shichao; as well as Fan Jinxiang and Liu Jia, "Challenges and Thoughts on Intelligent Guidance for Automatic Target Recognition."

${ }^{45}$ Fan Jinxiang and Liu Jia, "Challenges and Thoughts on Intelligent Guidance for Automatic Target Recognition."

${ }^{46}$ Fan Jinxiang and Liu Jia, "Challenges and Thoughts on Intelligent Guidance for Automatic Target Recognition."

${ }^{47}$ Fan Jinxiang and Liu Jia, "Challenges and Thoughts on Intelligent Guidance for Automatic Target Recognition."

${ }^{48}$ Jiang Jingchun, "Some Reflections on Accelerating the Development of China's Military Intelligence."

${ }^{49}$ Liu Yao, "Thoughts on Perfecting the Security Management System of Military Enterprises" [完善军工企业保密管理体系的思考], Confidentiality, April 15, 2019， http://www.cnki.com.cn/Article/CJFDTotal-BMGZ201904032.htm.

${ }^{50}$ Liu Yao, "Thoughts on Perfecting the Security Management System of Military Enterprises."

${ }^{51}$ Aaron Mehta, "'Unbelievably ridiculous': Four-star general seeks to clean up Pentagon's classification process," Defense News, January 29, 2020, https://www.defensenews.com/pentagon/2020/01/29/unbelievably-ridiculous-fourstar-general-seeks-to-clean-up-pentagons-classification-process/.

52 Jiang Jingchun, "Some Reflections on Accelerating the Development of China's Military Intelligence." 
${ }^{53}$ Li Sha-sha, Liu Dan, and Tang Jin-tao, professors in the College of Computer Science, China National University of Defense Technology, "Research on Teaching the 'Data Mining and Machine Learning' Course" [面向任职教育的“数据挖掘与机器学习”课程教学研究 ], Journal of Higher Education Research, March 15, 2019, https://gb.oversea.cnki.net/KCMS/detail/detail.aspx?filename=GJYJ201901017\&dbcod $\underline{\mathrm{e}=\mathrm{CJFD} \& d b n a m e=C J F D T E M P}$.

${ }^{54}$ Li Sha-sha, Liu Dan, and Tang Jin-tao, "Research on Teaching the 'Data Mining and Machine Learning' Course."

${ }^{55}$ Liu Yao, "Thoughts on Perfecting the Security Management System of Military Enterprises."

${ }^{56}$ Liu Yao, "Thoughts on Perfecting the Security Management System of Military Enterprises."

${ }^{57}$ Zhang Aimin, "The United States is Building an Artificial Intelligence 'Terminator," [美国 正打造人工智能 “终结者”], Military Digest, June 1, 2019, https: / / kns.cnki.net/KCMS/detail/detail.aspx? dbcode=CJFQ\&dbname=CJFDLAST2019\&f ilename=JSWN201911010\&v=Mic1NiFYMUxleFITNORoMVQzcVRyVO0xRnJDVVI3cWZ ZT1pzRmlyblVyN01MejdiWUxHNEg5ak5ybzlFWkISOGU=.

${ }^{58}$ Jiang Jingchun, "Some Reflections on Accelerating the Development of China's Military Intelligence."

${ }^{59}$ Jiang Jingchun, "Some Reflections on Accelerating the Development of China's Military Intelligence."

${ }^{60}$ See analysis by Saif M. Khan, "Maintaining the Al Chip Competitive Advantage of the United States and its Allies," Center for Security and Emerging Technology, December 2019, https://cset.georgetown.edu/wp-content/uploads/CSET-Maintaining-the-Al-ChipCompetitive-Advantage-of-the-United-States-and-its-Allies-20191206.pdf; and Lorand Laskai and Helen Toner, "Can China Grow Its Own Al Tech Base?," New America Foundation, November 4, 2019, https://www.newamerica.org/cybersecurityinitiative/digichina/blog/can-china-grow-its-own-ai-tech-base/.

${ }^{61}$ Song Liang and Ren Haifeng, "As New Technology Catches on Fire, the Microchip Industry Gradually Thaws" [新技术引燃星星之火，芯片产业生态坚冰渐融], Industrial Innovation, September 20, 2018, http://www.cycxyjzzs.com/2018/364.html.

${ }^{62}$ Song Liang and Ren Haifeng, "As New Technology Catches on Fire, the Microchip Industry Gradually Thaws."

${ }^{63}$ Song Liang and Ren Haifeng, "As New Technology Catches on Fire, the Microchip Industry Gradually Thaws."

${ }^{64}$ See recommendations by Andrew Imbrie, et al, "Agile Alliances," Center for Security and Emerging Technology, February 2020, https://cset.georgetown.edu/wp-

content/uploads/CSET-Agile-Alliances.pdf. 
${ }^{65}$ See recommendations by Tina Huang and Zachary Arnold, "Immigration Policy and the Global Competition for Al Talent," Center for Security and Emerging Technology, June 2020, https://cset.georgetown.edu/research/immigration-policy-and-the-globalcompetition-for-ai-talent/; and Imbrie et al, "Agile Alliances."

${ }^{66}$ See recommendations by Saif Khan and Carrick Flynn, "Maintaining China's Dependence on Democracies for Advanced Computer Chips," Brookings Institution and Center for Security and Emerging Technology, April 2020, https://cset.georgetown.edu/wpcontent/uploads/Khan-Flynn\%E2\%80\%94Maintaining-Chinas-Dependence-onDemocracies.pdf.

${ }^{67}$ Kensaku lhara, "Taiwan loses 3,000 chip engineers to 'Made in China 2025,'" Nikkei Asian Review, December 3, 2019, https://asia.nikkei.com/Business/China-tech/Taiwanloses-3-000-chip-engineers-to-Made-in-China-2025.

${ }^{68}$ Andrew Imbrie and Ryan Fedasiuk, "Untangling the web: Why the US needs allies to defend against Chinese technology transfer," Brookings Institution and Center for Security and Emerging Technology, April 2020, https://cset.georgetown.edu/wpcontent/uploads/Imbrie-Fedasiuk\%E2\%80\%94Untangling-the-Web.pdf.

${ }^{69}$ Imbrie, et al, "Agile Alliances."

70 See analysis by Melissa Flagg, "Global R\&D and a New Era of Alliances," Center for Security and Emerging Technology, June 2020,

https://cset.georgetown.edu/research/global-rd-and-a-new-era-of-alliances/

${ }^{71}$ Geist and John, "How Might Artificial Intelligence Affect the Risk of Nuclear War?"

${ }^{72}$ Michael C. Horowitz, Paul Scharre, and Alexander Velez-Green, "A Stable Nuclear Future? The Impact of Autonomous Systems and Artificial Intelligence," arXiv:1912.05291 [cs.CY], December 2019, https://arxiv.org/ftp/arxiv/papers/1912/1912.05291.pdf.

73 "IISS Shangri La Dialogue 2019," International Institute for Strategic Studies, accessed April 2020, https://www.iiss.org/events/shangri-la-dialogue/shangri-la-dialogue-2019.

${ }^{74}$ Some DARPA-sponsored project teams already publish detailed whitepapers about their successes and failures in developing machine learning applications. For example, see progress in DARPA's Media Forensics (MediFor) Challenge. Haiying Guan, et al, "MFC Datasets: Large-Scale Benchmark Datasets for Media Forensic Challenge Evaluation," National Institute of Standards and Technology, July 23, 2019, https://tsapps.nist.gov/publication/get pdf.cfm?pub id=927035.

${ }^{75}$ Andrew Imbrie and Elsa Kania, "Al Safety, Security, and Stability Among Great Powers," Center for Security and Emerging Technology, December 2019, hitps://cset.georgetown.edu/wp-content/uploads/Al-Safety-Security-and-StabilityAmong-the-Great-Powers.pdf.

${ }^{76}$ Austin Long, "Chapter 5: U.S. Nuclear Strategy toward China: Damage Limitation and 
Extended Deterrence," in America's Nuclear Crossroads (Washington: CATO Institute, 2019), https://www.cato.org/sites/cato.org/files/pdfs/americas-nuclear-crossroadsfull.pdf.

77 Luke O'Brien, "Whither Skynet? An American 'Dead Hand' Should Remain a Dead Issue," War On the Rocks, September 1 1, 2019, https://warontherocks.com/2019/09/whitherskynet-an-american-dead-hand-should-remain-a-dead-issue/.

${ }^{78}$ James Acton, "Is It a Nuke?: Pre-Launch Ambiguity and Inadvertent Escalation," Carnegie Endowment for International Peace, April 9, 2020, https://carnegieendowment.org/2020/04/09/is-it-nuke-pre-launch-ambiguity-andinadvertent-escalation-pub-81446.

${ }^{79}$ Lora Saalman's work indicates this should be a serious concern, especially as weapon speed increases and projected flight times-to-target decrease. See "Fear of false negatives: Al and China's nuclear posture."

${ }^{80}$ See examples of system failure in Paul Scharre, "Autonomous Weapons and Operational Risk," Center for a New American Security, February 29, 2016, https://www.cnas.org/publications/reports/autonomous-weapons-and-operational-risk.

${ }^{81}$ Kelsey Atherton, "Pentagon will start figuring out Al for lethality in 2020," C4ISRNET, January 22, 2020, https://www.c4isrnet.com/artificialintelligence/2020/01/22/pentagon-will-start-figuring-out-ai-for-lethality-in-2021.

${ }^{82}$ This finding differs significantly from prior analysis by Lora Saalman in "Fear of false negatives: Al and China's nuclear posture." One explanation is that automated missile launch is less likely to be discussed in open literature, and this study is restricted to a publicly available corpus.

${ }^{83}$ For the original Gaither report, see "Deterrence and Survival in the Nuclear Age," Security Resources Panel of the U.S. Science Advisory Committee, November 7, 1957, https://nsarchive2.gwu.edu//NSAEBB/NSAEBB139/nitze02.pdf.

${ }^{84}$ For discussions of U.S. limitations in developing Al, see Michael Horowitz, "The promise and peril of military applications of artificial intelligence," Bulletin of the Atomic Scientists, April 23, 2018, https://thebulletin.org/2018/04/the-promise-and-peril-of-militaryapplications-of-artificial-intelligence/. For additional perspective, see performances at the championship of the world first autonomous drone racing competition (video): "Austin races pair up drones, Al technology," The Statesman YouTube channel, December 6, 2019, hitps://youtu.be/SLouoluQGRY.

85 "China National Knowledge Infrastructure: FAQ," EastView Information Services, accessed January 2020, hitps://www.eastview.com/resources/cnkifaq/\# Toc 109472940.

86 "CNKI Introduction," CNKI Scholar, accessed February 2020, http://eng.scholar.cnki.net/about/intro.aspx. 
${ }^{87}$ The author searched for both Chinese and English keywords because, although the vast majority of CNKI papers are written only in Chinese, some did include English-language abstracts.

${ }^{88}$ While PhD dissertations and course syllabi can be instructive, course syllabi generally lack sufficient detail for analysis and dissertations were not as representative of scholarly thinking as published papers. 